\title{
CHALLENGE AND OPPORTUNITY: THE ALI/III GLOBAL PRINCIPLES PROJECT
}

\author{
IF Fletcher*
}

\section{Introduction}

In February 2006 the American Law Institute (ALI) and the International Insolvency Institute (III or Triple-I) announced the inception of a joint dissemination and extension project with respect to the Principles of Cooperation developed in the ALI Transnational Insolvency Project. ${ }^{1}$ The stated objective of the two bodies was to establish acceptance of the ALI's Principles of Cooperation among the NAFTA Countries in jurisdictions across the world, subject to any necessary local modifications, and to obtain the endorsement of leading domestic associations, courts, and other groups in those jurisdictions. The Joint Reporters for this project are the present author, together with Professor Bob Wessels. The intended time frame for completion was set at within 24 to 30 months, thereby envisaging the production of a finalised text before the end of the year 2008. It was also anticipated that the Joint Reporters would carry out their task in collaboration with an International Advisory Group whose membership would be drawn primarily from the international membership of III. Given the specialised nature of the subject matter of the project, and also its international character, the technical expertise and professional stature of the III membership makes them ideally qualified for the task in hand. ALI members with an interest in the field of international

* Professor of International Commercial Law, University College London. This paper was originally delivered at the conference of the Academics' Group of INSOL International, held in Cape Town on 17-21 March 2007.

1 See below, n 3 and 4, and text thereto. 
bankruptcy are also participating, even if they do not happen to be members of III. ${ }^{2}$ In addition, an ALI Members' Consultative Group has been formed in accordance with the organisation's usual procedure for the conduct of projects.

\section{Background: the ALI NAFTA Insolvency Project}

The American Law Institute's NAFTA Insolvency Project, for which Professor Jay L Westbrook was the US Reporter, was conceived as a means of seeking common ground and shared principles among the laws of the three NAFTA countries with regard to the conduct of cross-border bankruptcies. ${ }^{3}$ The inception of the North American Free Trade Agreement (NAFTA) in December 1992 represented a new point of departure for regionally-based collaboration in the Americas. Each of the three participating States - Canada, Mexico and the United States of America - is a significant economic entity in its own right. When the three economies became linked in a joint venture to establish a free trade area, the prospective economic advantages were enormous. But these were accompanied by potential legal complexities that might afflict any transnational commercial structures or business relationships built across the frontiers of the component states. In terms of legal cultures and affinities, Mexico belongs to the Hispanic branch of the civil law 'family', with codified laws whose application is predicated upon judicial fidelity to the legislator's expressed intentions. On the other hand, both Canada and the United States can trace their legal lineage back to English common law, with its historic emphasis on the role of an independent judiciary endowed with powers of a

2 The Co-Chairs of the International Advisory Group are Professor Jay L Westbrook, the Reporter for the NAFTA Principles Project, and E Bruce Leonard, who was Chair and Reporter for Domestic Aspects of Canadian Law for the previous project, and who is currently Chair of the III.

3 Westbrook and Ziegel 1997 Brook J Int'l L 7-24. 
discretionary nature enabling the judge to exercise initiative in developing suitable responses to changing social needs. Despite their common ancestry, however, the two systems are by no means identical and their present-day state of evolution is in part a reflection of their different histories in the transition from colonial status to independent statehood. Moreover, while the laws of the majority of the provinces and states within Canada and the United States respectively are common law-based, there are the exceptional cases of the Province of Quebec in Canada and the State of Louisiana in the United States where - to differing degrees - the legal system and its working practices are traceable to the French branch of the civil law family. Given this mixture of legal styles and systems, the practical difficulties of ensuring a stable platform on which parties can conduct their business affairs under the NAFTA are considerable. In addition, the absence of a central court of justice, comparable to the European Court of Justice (ECJ), makes it imperative that the national courts of the three participating States be provided with appropriate tools with which to set about resolving cases arising in the context of the free trade agreement, in which the interests of private parties and entities are engaged.

Among the matters requiring such attention are the problems resulting from the insolvency of a party engaged in transnational relationships. The ALI Transnational Insolvency Project was established to address this need by providing authoritative guidance to courts and lawyers within the multijurisdictional legal environment of the NAFTA To this end an unusually intense, systematic programme of investigative study was employed. Advisory committees were formed comprised of experts from each of the three countries, together with some consultants and advisors from non-NAFTA countries. The work was divided into two phases. ${ }^{4}$ In the first phase, each of the three

4 The author served as an adviser to the Project from 1999 onwards. For accounts of the work of the ALI Insolvency Project during its successive phases, see Westbrook and $3 / 28$ 
committees prepared a concise, but authoritative, International Statement of that country's insolvency law as applicable to international cases, written with a non-domestic audience in mind. Care was also taken to ensure that the statements conveyed an accurate picture of what actually takes place under the legal processes operative within each system, rather than merely presenting a decontextualised summary of the provisions of the enacted law. Each of the three statements was translated into the official languages of the other two participating states, and published in 2003 within a set of four volumes which together comprise the fruits of the ALI Transnational Insolvency Project. ${ }^{5}$ Given the mixture of legal traditions to which the three NAFTA Member States respectively belong, the doctrinal and practical issues encountered in this process were in many ways a microcosm of those which arise in other geographical regions of the world, and indeed in situations involving a globallyconstituted mixture of jurisdictions. Thus the fruits of this part of the ALI project, and indeed of the project as a whole, are undoubtedly of wider interest and relevance than in an exclusively NAFTA context alone.

The second phase of the ALI project built upon the insights obtained during phase one, culminating in the preparation of a one-volume treatise entitled: Principles of Co-operation among the NAFTA Countries. This document, which was approved by the Council and Members of the ALI at the organisation's Annual Meeting in May 2000, represents the consensus among all those

Ziegel 1997 Brook J Int'l L 7-24; Westbrook Managing Defaulting Multinationals; and Westbrook 2002 Am Bankr LJ 1.

5 Each of the four volumes bears the main title: Transnational Insolvency: Co-operation among the NAFTA Countries, followed by the appropriate subtitle. In the case of the three national reports, the subtitle is specific to the country in question: "International Statement of Mexican/Canadian/United States Bankruptcy Law" (as appropriate). The fourth volume, bearing the subtitle "Principles of Cooperation among the NAFTA Countries", is the product of the $2^{\text {nd }}$ phase of the ALI Project, discussed below. See ALI Canadian Bankruptcy Law; ALI Mexican Bankruptcy Law; ALI US Bankruptcy Law; and ALI Principles of Cooperation. 
participating in the two phases of the project, as well as bearing the endorsement of the $\mathrm{ALI}$ itself. ${ }^{6}$ As already observed, the rigorous comparative study which preceded the formulation of the principles has supplied the latter with an empirical platform which ensures that they are not only robust in terms of the particular context in which they are intended to be applied, but also potentially adaptable to non-NAFTA bankruptcy proceedings.

One additional matter to be noted is the intellectual continuity between the ALI principles and other, near-contemporaneous developments. Both the philosophy of approach, and the substance of the principles articulated, exhibit a natural affinity with those which are to be found in the UNCITRAL Model Law on Cross-Border Insolvency $1997,{ }^{7}$ which in turn can be seen to have assimilated the fruits of the two most recent European projects, namely the Istanbul Convention of the Council of Europe and the EC Regulation on Insolvency Proceedings. Notions of co-operation and recognition, of the sharing of information and the facilitation of prompt and effective action for the preservation of value - especially by means of a moratorium - and for achieving equitable distribution among creditors on a basis of nondiscrimination, are all conspicuously present. ${ }^{8}$ Access to the courts of the other participating states, access to relevant information, and the free flow of communication between the courts of different states, are among the key principles espoused in the text. ${ }^{9}$ As with the Model Law, the ALI NAFTA

6 The final text of the ALI "Principles of Co-operation", then labeled Tentative Draft (14 April 2000) was finally approved by the ALI Annual Meeting on 16 May 2000. After some further editorial adjustment, this text was published in 2003, together with the other three volumes referred to in $\mathrm{n} 5$.

7 UNCITRAL Model Law http://www.uncitral.org/ 31 Aug (hereinafter 'Model Law').

8 ALI Principles of Cooperation, (hereinafter referred to as NAFTA Principles), s III, General Principles: Principles I-VII.

9 Ibid, s IV, Procedural Principles, esp pr 1-10, 14-16. See also app B to the Statement of Principles, which bears the title Guidelines Applicable to Court-to-Court Communications in Cross-Border Cases. The latter text contains 17 numbered guidelines intended to enhance co-ordination and harmonisation in multi-jurisdictional insolvency cases. 
Principles allocate a pivotal role in the management and conduct of international cases to the judges exercising jurisdiction in the respective countries concerned. To achieve this goal of enhanced judicial empowerment which is such a characteristic feature of the common law tradition but accords less readily with the civilian legal culture which is also prominently represented within the NAFTA countries - the Principles also include a section containing seven specific recommendations which are aimed at securing a complementary framework of enacted provisions within the laws of each participating state, conferring upon the judge a positive mandate for the conduct of cases in accordance with the foregoing General and Procedural Principles. ${ }^{10}$ To facilitate the application of the principles in the course of live proceedings, appendix B sets out a code of practice in the form of Guidelines Applicable to Court-to-Court Communications in Cross-Border Cases, which are intended to be adopted on a dynamic and flexible basis to allow the courts to respond to the requirements of actual situations encountered over time.

Following formal adoption in May 2000 of the final draft of the NAFTA Principles together with the International Statements of the laws of the three NAFTA countries, a collaborative process developed between the ALI and III, utilising the extensive network of expertise and high-level contacts among the global membership of the latter organisation. Perceiving the special relevance of the Guidelines Applicable to Court-to-Court Communications in Cross-Border Cases for use in situations transcending the NAFTA countries alone, III arranged for a series of translations to be made (there have been some 13 to date), and it also circulated the Guidelines to virtually every significant commercial or bankruptcy court in the major economies of the world. The ALI has published the Guidelines in bilingual editions so that the original authentic 
English version appears in every copy that is distributed. However, merely disseminating the ALI work product, even if in a translation to facilitate the accessibility of the text to readers who may be unused to reading technical literature in English, does not of itself guarantee that the text will be read, much less that it will be accepted and acted upon. For there to be a realistic prospect that courts operating outside the NAFTA countries will embrace the Guidelines, and major parts of the NAFTA Principles of which they form a part, a more active process of engagement would be required. This would include some form of meaningful interchange conducted by way of an expert dialogue with qualified representatives of the legal system of each country in turn, with a view to ascertaining the extent to which the Principles can serve as the basis for a formulation of global standards in terms of rules and principles applicable in the transnational insolvency process. It was with this objective that the ALI/III Global Principles Project was conceived during 2006, and established as explained above in the Introduction. The present paper seeks to delineate the nature and scale of the challenge presented by this project, and also to indicate the approach which has been adopted by the Joint Reporters in response to that challenge.

\section{The challenge: defining the objectives of the Global Principles Project}

The Joint Reporters set about their mission by drawing up a provisional statement of objectives, with a view first to launching an interactive discussion with the membership of the Advisory Group, and thereafter to refining and reshaping the objectives themselves. The provisional statement, provocatively titled as 'Manifesto of Aims and Objectives', took as its starting proposition that the central raison d'être of the project was already defined, namely to establish the extent to which it is feasible to achieve a worldwide acceptance of the NAFTA Principles together with the Guidelines Applicable to Court-to-Court 
Communications in Cross-Border Cases (the Guidelines). To attain this primary goal it seemed appropriate to design a systematic consultation exercise, drawing on the expert, first-hand knowledge of members of the Advisory Group, to determine the extent to which the NAFTA Principles and also the Guidelines are capable of being applied within a wide and representative range of legal systems around the world, and also the extent to which current practice in those countries may be said to conform to those standards. Conversely, to the extent that local circumstances give rise to any obstacles to the acceptance of such standards and practices, these should be identified, and consideration should then be given to possible means of resolving them.

Secondly the reporters perceived that the Global Principles Project could provide an appropriate vehicle for exploring further the possibilities for devising global standards to regulate the transnational insolvency process itself. A number of issues which have an important bearing upon the overall quality and efficiency of the international insolvency 'process' were either not directly addressed in the context of the NAFTA Principles Project, or were there dealt with on a somewhat tentative basis. These include the principles and procedures to be applied where insolvency occurs within multinational corporate groups (the subject of Procedural Principles 23 and 24 of the NAFTA Principles). Further issues which are self-evidently in need of study and development are the conflict of laws aspects of insolvency, including choice of law rules and the principles relating to the exercise of jurisdiction, together with the elaboration of internationally tenable definitions of some of the fundamental concepts employed in the standardised principles. Also of direct relevance to the goal of promoting effective co-operation in international cases are some very practical questions, including how to overcome the inevitable problems where the respective courts are operating concurrently in different regions and time zones, and have different working languages. In such situations, direct communication between courts may be impracticable, but it may be that some 
alternative means of achieving cooperation through one or more designated intermediaries could be established.

Thirdly, the reporters considered this could be a timely opportunity to take account of the considerable volume of work that has already been carried in this field in recent years. The number of recent projects and studies which either directly or indirectly relate to insolvency matters amount to a striking demonstration of the globalisation of commercial activity in the present era, and the raised awareness internationally of the need to address insolvency-related issues which arise in a cross-border context. It would therefore seem useful to enlist the collective wisdom of the International Advisory Group to try to distil, and if possible synthesise, the fruits of recent activity, and hopefully thereby provide a legislative tool which can be a point of reference in future. In addition to the NAFTA Principles themselves, including the Guidelines referred to above, the Joint Reporters have identified the following as of particular interest and relevance for the purposes of the current project:

- Asian Development Bank Good Practice Standards for Insolvency Law 2000

- World Bank Principles and Guidelines for Effective Insolvency and Creditor Rights Systems 2001, revised 2004

- Principles of European Insolvency Law 2003

- European Bank for Reconstruction and Development Core Principles for an Insolvency Law Regime 2004

- American Law Institute/UNIDROIT Principles of Transnational Civil Procedure 2004

- UNCITRAL Legislative Guide on Insolvency Law 2004

- INSOL Europe Academic Wing: European Communication and Cooperation Guidelines for Cross-Border Insolvency (draft 2006) 
To the extent that the above are able to supply indications of existing points of agreement on matters of principle, or in respect of the processes to be encouraged as exemplifying current standards of best practice, they will be taken into account in the course of the Global Principles Project. ${ }^{11}$

\subsection{First steps in consultation}

A meeting with the inaugural members of the Advisory Group was convened at Columbia University School of Law on June 14 2006, attended by judges, practitioners and academics from more than 10 countries. The meeting reviewed the reporters' provisional statement of aims and objectives and discussed a number of associated themes which could potentially be included within the revised objectives. There was a consensus on the need to maximise the opportunities presented by the assembling of a globally-drawn group of experts by examining, within the limits of reasonableness, certain related issues which those engaged in the NAFTA Principles Project had not managed to resolve. For example it was considered that some of the practical aspects of cross-border cooperation should be addressed, including, as already mentioned, the resolution of differences of working languages of the courts involved, and of the time zones in which the respective courts are located. There was also some support for the suggestion that the special difficulties encountered in insolvencies of multinational groups of companies are in urgent need of attention, although it was quickly realised that the complexity of the subject could pose problems of balanced allocation of the available resources. The subsequent decision by UNCITRAL, at its meeting in July $2006,{ }^{12}$ to

11 With this task in mind, a Taxonomy of Guidelines and Principles in International Insolvency was drawn up with the assistance of Dr Paul Omar. See Omar Taxonomy (currently unpublished), which provides a synoptic display of the principles formulated by 8 different studies, arranged thematically (copy on file with author).

12 UNCITRAL Report of $39^{\text {th }}$ Session http://www.uncitral.org 11 Mar at par 207-209(a). 
establish a Working Group to consider the treatment of corporate groups in insolvency has obviated the need for this topic to be brought within the main objectives of the Global Principles Project, although it need not altogether preclude our consideration of some aspects where appropriate. As a consequence of this development it was decided that the project should focus attention upon some of the more pressing issues in the area of private international law which to date have defeated the attempts of international organisations to devise clear and workable solutions.

\subsection{Taking the project forward 2007-2008}

Following a period of reflection in the wake of the initial meeting with the Advisory Group, the reporters' next goal was to bring about the augmentation of the membership of the group with a view to its being as widely representative as possible. Concurrently, a systematic questionnaire has been designed to enable us to test the degree of acceptance of the NAFTA Principles among the states whose systems can be interrogated via the collective expertise of the group. Additional questions will then be formulated to try to gather reliable data concerning the issues referred to above, and afterwards to yield insights into the readiness of the global community of states to embrace even a limited number of standardised rules and practices which would bring greater stability to debtor-creditor relations.

Going forward, the Joint Reporters wish to emphasise their belief in the need to maintain an open-minded spirit of inquiry, and a transparent process of debate, to ensure that any aspects of the Principles which may give rise to difficulties of transposition into the legal culture of a particular country or region can be properly and sensitively considered. If any particular issue cannot be resolved on the basis of a text of universal application acceptable to all, an accommodation may be sought by means of a proviso to allow the main principle to operate subject to certain necessary local modifications. In the 
course of this process, the extant array of internationally generated texts which were referred to above will be studied with a view to ascertaining additional, complementary principles of law and practice which are considered to command general support. In this way it is hoped that the final text embodying the Global Principles will obtain the approbation of governmental authorities, domestic and international organisations, practitioners, and (most importantly) courts in their approach to the conduct of international insolvency matters in the future.

\section{$4 \quad$ Widening the opportunity involvement in the Global Principles Project}

The Joint Reporters are only too well aware of the sheer magnitude of the task they have undertaken. To conduct a survey of even a representative selection of legal systems - perhaps 20 or 25 in number - requires a considerable allocation of their time by experts whose knowledge and skills are already much in demand. The working practices of the two bodies under whose auspices this project is being conducted - the $A L I$ and the III - require that formal membership of the International Advisory Group or the ALI Members' Consultative Group operating in accordance with our terms of reference is restricted to persons who are themselves members of either the ALI or the III. Some, indeed, happen to belong to both organisations. We are however very keenly aware of the reservoir of talent and scholarly wisdom that exists within the membership of other organisations with an interest in international insolvency matters, such as the Academics' Group of INSOL International. We have therefore formed an additional circle of consultees comprising experts who are not currently members of either the ALI or the III. We believe that they will make a valuable contribution to the project, for example by providing us with critical insights into the issues affecting a wider range of jurisdictions with which they happen to be personally familiar. 


\section{Subject for further consideration: the challenge of harmonisation of rules of private international law}

When courts engage in cross-border cooperation, it can scarcely be supposed that they do so under circumstances where each court is blind to the international implications of the action it is being invited to take at the request of its foreign counterpart, or of interested parties including, most prominently, the foreign representative. For reasons that are well understood among those conversant with bankruptcy and insolvency matters, existing instruments which regulate aspects of international insolvency, even including the EC Regulation on Insolvency Proceedings, have stopped short of seeking to unify the domestic insolvency laws of the states affected.

For the foreseeable future therefore it will continue to be relevant to know in which jurisdiction a given debtor is capable of becoming subject to insolvency proceedings, and what will be the substantive consequences of those proceedings for all concerned. For the purposes of international recognition and enforcement of the effects of such proceedings, as well as for the purpose of obtaining the cooperation and assistance of foreign courts pursuant to such arrangements as are put in place following enactment of the UNCITRAL Model Law, the court hearing the foreign request must evaluate the circumstances in which the foreign proceedings came to be opened, and may also need to establish such questions as the precise time at which proceedings are to be treated as having opened. Regrettably, at present there is an absence of clear, universally agreed rules to determine these issues, so that the outcome of such crucial legal questions can be unpredictable at best. This is unfortunately the case even in respect of the EC Regulation and the UNCITRAL Model Law, whose recourse to a near-common vocabulary by the use of key concepts such as 'centre of main interests' and 'establishment' seemed initially to herald a 
significant leap forward in the standardisation of rules of jurisdiction. Despite the enormous efforts expended in negotiating and drafting them, neither the EC Regulation nor the Model Law succeeded in providing a clear and precise definition of 'centre of main interests', while their respective definitions of 'establishment' may also prove to be difficult to apply in relation to some forms of commercial activity. ${ }^{13}$ This definitional deficit has already proved to be the source of troublesome and costly uncertainty in the operation of the EC Regulation, as it can give rise to disputes between interested parties as to the legitimacy of attempts to open proceedings in a given jurisdiction. ${ }^{14}$ Similar difficulties, bringing in their wake a plethora of legal uncertainties, have resulted from the lack of technical precision in the drafting of the EC Regulation's definition of 'time of the opening of proceedings'. ${ }^{15}$ This is a serious defect in view of the notorious problem of the 'race to the courthouse', which has a long history in the realm of cross-border insolvency.

The fraught questions of jurisdiction in international insolvency cases, and the vital matter of definition in respect of the concepts embodied in any jurisdictional rule, are inextricably linked to the process of allocating the substantive law by which any insolvency proceedings (or any aspects of such proceedings) are to be governed. The EC Regulation seeks to control these issues by declaring, in its article 4(1), that the law applicable to insolvency proceedings and their effects shall be that of the Member State within whose

13 Definitions of 'establishment' are supplied in art 2(h) of the EC Regulation and in art 2(f) of the UNCITRAL Model Law. The two definitions are closely similar, but not identical in their wording.

14 See eg Case C-341/04, Re Eurofood IFSC Ltd [2006] ECR I-4137; [2006] BCC 397 (ECJ) of 2 May 2006; Re Daisytek-ISA Ltd [2003] BCC 562 (Ch D Leeds Registry) 16 May 2003; Klempka v ISA Daisytek SA [2003] BCC 984 (Court of Appeal, Versailles) 4 September 2003.

15 See art 2(f) of the EC Regulation. The meaning of this provision was one of the issues referred to the ECJ in the Eurofood case (see $n$ 14). The court abstained from deciding all aspects of this issue of interpretation, leaving further uncertainties about the full effects of the provision. 
territory such proceedings are opened. However, this basic rule is subject to specific exceptions prescribed in the next following articles numbered from five to 15 inclusive. The extent to which such extensive exceptions to the controlling effect of the lex concursus have proved necessary, under current circumstances of diversity even among the laws of such closely aligned states as those belonging to the European Union, demonstrates the need for extreme caution when attempting to design a scheme of choice of law rules for application on a wider, global canvas. In the author's estimation, it would be politically naïve to suppose that sovereign states would currently be prepared to surrender the benefits of locally generated rules under which parties may have based their expectations in their dealings with a debtor, by conceding complete and overarching control to the provisions of some foreign insolvency law under which the debtor's global estate comes to be administered. For this reason it is especially disappointing that the authors of the UNCITRAL Legislative Guide, when dealing with the linked subjects of jurisdiction and choice of law, chose to abandon their otherwise admirable policy of refraining from an overlyprescriptive presentation of their advice by proclaiming their preference for an unvarying application of the lex concursus. ${ }^{16}$ While some of the provisions of the EC Regulation which create exceptions to the application of the lex concursus are also not without difficulty in terms of their conception and drafting, ${ }^{17}$ it is surely premature - and not a little presumptuous - for the

16 UNCITRAL Legislative Guide http://www.uncitral.org/ 19 Feb part 2, ch I, s C, Applicable Law in Insolvency Proceedings. For the author's criticism of the approach taken in that section of the Guide, see Fletcher Insolvency in Private International Law, ch 9, par 9.13 to 9.16 .

17 An example would be the provisions of art 6 of the EC Regulation, concerning the availability of set-off in cases where this would be precluded under the provisions of the lex concursus. As is explained in the remaining part of this section of the paper, during the formative process of the Draft Convention on Insolvency Proceedings (the textual precursor to the current Regulation), several alternative versions of what is currently art 6 were produced, based on a variety of approaches to the central problem of how to accommodate the legitimate expectations of parties dealing with the debtor under circumstances where mutual debits and credits would or might be produced. The rule $15 / 28$ 
authors of the Legislative Guide to suggest that there is a consensus among economically advanced nations that the unchallenged domination of the lex concursus currently represents 'best practice' in the selection of the law to govern all aspects of an international insolvency case.

The above considerations lead the author to conclude that it would be useful to devote some time during the conduct of the Global Principles Project to an effort to ascertain the extent to which agreement can be reached on such matters as the definition of key terms employed in the rules governing jurisdiction and choice of law, and in the actual content of the rules for selection of the applicable law in cross-border cases. The following survey of some of the positions explored during the evolution of the EC Regulation's special rule (in article 6) to permit set-off to be claimed in certain circumstances despite the fact that the law of the State of the opening of insolvency proceedings does not allow set-off to operate, is offered here as an illustrative case study of the kind of issues which might be revisited with the aim of devising a rule that could be accepted by a wider international community beyond the frontiers of the European Union.

finally adopted - whereby set-off is claimable if it is "permitted by the law applicable to the insolvent debtor's claim" is by no means self-evidently the most appropriate solution to the issues of principle which arise in relation to international set-off. The subject undoubtedly merits a re-examination as part of the process of devising rules which are intended to be applied as globally accepted norms. 
5.1 Set-off by way of exception to the regime of the lex concursus: is Article 6 of Council Regulation (EC) 1346/2000 the most appropriate rule?

Article 6 is one of a series of articles in the EC Regulation on Insolvency Proceedings (namely, articles 5 to 15 inclusive) which generate special rules applicable by way of exception to the general rule laid down by article 4(1) that

the law applicable to insolvency proceedings and their effects shall be that of the Member State within the territory of which they are opened. (the lex concursus)

The general rule of article 4(1) is reinforced by a specific provision in article $4(2)(d)$ to the effect that the lex concursus shall determine in particular "the conditions under which set-offs may be invoked". However, the opening words of article 4(1) indicate that its provisions are subject to exception where there is contrary provision elsewhere in the regulation itself. Such a contrary provision, in relation to set-off, is made by article 6 . Article 6(1) states:

The opening of insolvency proceedings shall not affect the right of creditors to demand the set-off of their claims against the claims of the debtor, where such a set-off is permitted by the law applicable to the insolvent debtor's claim.

The exception thereby created is of a very precise character. As explained in the Virgós-Schmit Report, in the comment to article 6 of the EC Convention on Insolvency Proceedings (whose drafting is in every respect identical to that of article 6 of the regulation), the intention of this provision was that -

When under the normally applicable rules of conflict of laws the right to demand the set-off stems from a national law other than the "lex concursus', Article 6 allows the creditor to retain this possibility as an 
acquired right against the insolvency proceedings: the right to set-off is not affected by the opening of proceedings. ${ }^{18}$

The reference to "the normally applicable rules of conflict of laws" is especially significant because, as is well understood, those rules are capable of giving rise to a situation where contractual or other liabilities are governed by the laws of (potentially) any state in the world. In relation to contractual obligations, this possibility is accepted by the express provision in article 2 of the EC Convention of 19 June 1980 on the Law Applicable to Contractual Obligations (the Rome Convention), which declares that:

Any law specified by this Convention shall be applied whether or not it is the law of a Contracting State.

As the Rome Convention is applicable in all the current EC Member States, ${ }^{19}$ the literal and natural meaning of the expression "the law applicable to the insolvent debtor's claim" in article 6(1) of the regulation is that it means any law capable of being identified as the applicable law of the obligation in question according to the choice of law rules now standardised among EU Member States by the Rome Convention. Of course, non-EU States' rules of choice of law in contractual matters are not affected by the Rome Convention, and retain that diversity of approach for which the realm of private international law is notorious.

18 Virgós-Schmit Report, par 107, second sentence. (The Report, which was not officially adopted or published by the EC Council which commissioned its preparation during 19951996 as an aid to interpretation of the EC Convention on Insolvency Proceedings, has been published in several textbooks and commentaries, including Fletcher supra n 16, app VII).

19 As new Member States have joined the EU since 1980, accession to the Rome Convention has been included among the terms of entry negotiated between the EU and its existing members and the candidates for membership. Eg Spain (together with Portugal) acceded to the Rome Convention with effect from 1 September 1993 upon ratification of the Funchal Convention of 18 May 1992 (OJ 1992, C333/1).

$18 / 28$ 
The above rationalisation of the conclusions that follow upon an examination of the literal and natural meaning of article 6 is fully consistent with the interpretative guidance supplied by recital (26) to the regulation. The recitals are destined to play an important role in the interpretation of the regulation, both by national courts and by the ECJ. They were incorporated into the text with the intention (in part) of compensating for the absence of any official document in the form of an explanatory report to the regulation (equivalent to the intended function of the Virgós-Schmit Report in relation to the planned Convention). Recital (26) (which is closely modeled upon statements contained in paragraph 109 of the Virgós-Schmit Report), states as follows:

If a set-off is not permitted under the law of the opening State, a creditor should nevertheless be entitled to the set-off if it is possible under the law applicable to the claim of the insolvent debtor. In this way, set-off will acquire a kind of guarantee function based on legal provisions on which the creditor concerned can rely at the time when the claim arises.

\subsection{The textual history of article 6}

It is noteworthy that article 6 contains no words expressly restricting the scope of the exception to cases where the obligation through which the right to claim set-off is generated is governed by the law of one of the other EU Member States. The rule could therefore be considered as a candidate for more universal acceptance as an exception to the dominant role of the lex concursus in insolvency proceedings opened in any jurisdiction. In the course of developing the provision now embodied in article 6 , the members of the committee of experts established by the EC Council explored a number of alternative formulations which reflect a changing balance of opinion as to the correct principle to be applied. It is instructive to examine the textual history of this provision by studying the successive drafts produced and discussed by the committee of experts. 
During the concluding phase of the process of elaboration of the Draft Convention on Insolvency Proceedings, between May 1989 until September 1995, the provision allowing set-off to operate by way of exception to any exclusionary policy to be found in the lex concursus was the subject of extensive deliberation, during the course of which its substance and effect underwent a fundamental transformation. The rule in its current form, as quoted above, only appears in the draft versions of the convention produced after July 1993. Until that date, the proposed provision relating to set-off was expressed in the following terms:

The opening of insolvency proceedings shall not affect the right of creditors to the set-off of a claim forming part of the estate where the law of a Contracting State other than the State of the opening of proceedings applies to that claim. ${ }^{20}$ (italics added)

In the subsequent versions of the provision, eventually numbered as article 6 in the final text of the Convention as opened for signature in September 1995 and also in the regulation as adopted in May 2000, the drafting was significantly altered with the omission of any reference to the law of a Contracting/Member State, and with the inclusion of wording to clarify the scope of the rule so as to confine its operation to those cases where the right of set-off is permitted by the law applicable to the insolvent debtor's claim (that is, the claim under which the insolvent debtor stands as creditor towards the party seeking to invoke a right of set-off).

20 The version of the text as quoted appears as art 4.2 of the Preliminary Draft Convention on Insolvency Proceedings produced in 1991 as document 5419/91 (ANNEX), and as art 4a in the version of the Draft EC Bankruptcy Convention produced in 1993 bearing the reference $7163 / 93$. 


\subsection{What is the most appropriate rule for global application?}

What may require further consideration, especially when devising a rule for application in proceedings opened in any part of the world, is whether the reference to the law applicable to the insolvent debtor's claim, rather than the law governing the obligation under which the insolvent debtor occupies the role of debtor towards the other party, is the appropriate rule in principle, or whether it should be possible to invoke set-off if such a right is available under the law applicable to either claim, or (more restrictively) only if such a right can be shown to be available under the law or laws applicable to both claims assuming neither claim to be governed by the lex concursus. ${ }^{21}$

As a further issue for consideration, it may be questioned whether international set-off should be available merely on proof that such entitlement arises under one or other of the laws by which the mutual cross-obligations are governed, or whether there should be a further requirement that the party invoking set-off must show that such a right has formed part of the legitimate expectations arising in the context of the relationship between the creditor and the insolvent debtor, so as to have been part of the calculation of risk during the process of becoming a creditor on the terms agreed. Since it is a fundamental policy of insolvency law that all creditors are eligible to participate upon terms of global equality, any rule which introduces an exception to the pari passu principle needs to be justified with care, and should not be allowed to operate as a capricious or arbitrary device without regard to the context under which parties have had dealings with the debtor.

21 Unless the lex concursus itself permits set-off, in which case the need to invoke the exception would not arise. 


\subsection{The rationale of the EC Regulation's set-off rule}

The final intentions of the EC Committee of experts are summed up by a passage in paragraph 109 of the Virgós-Schmit Report (which, as was noted above, supplied the basis for the statement contained in recital (26) to the regulation):

If the 'lex concursus' allows for set-off, no problem will arise and Article 4 should be applied in order to claim the set-off as provided for by the law. On the other hand, if the 'lex concursus' does not allow for set-off (e.g. since it requires both claims to be liquidated, matured and payable prior to a certain date), then Article 6 constitutes an exception to the general application of that law in this respect, by permitting the set-off according to the conditions established for insolvency set-off by the law applicable to the insolvent debtor's claim ('passive' claim). (italics added)

In adopting the rule of article 6, whereby the policy of the lex concursus is displaced by that of the law applicable to the passive claim (in situations where there is a true conflict between the two laws with regard to the availability of set-off in casu), the authors of the regulation (and of the convention that preceded it) were giving effect to the doctrine which scholars of the modern era seem to regard as the more satisfactory rule of decision for international cases. The 'traditional' approach, as advocated by a number of writers in former times, required the cumulative application of both laws - that is, those governing the active and the passive claim respectively - and would deny set-off unless both laws were found to concur in allowing it to operate. Modern analysis, on the other hand, has placed greater emphasis on the need to protect legitimate and reasonable expectations, and therefore on the need for a stable rule that enables the creditor to rely upon the provisions of a single system of law whose provisions are applicable in the context of his incurring an obligation towards the party who is subsequently the subject of insolvency proceedings. There appears to be a growing consensus among modern scholars that such stability and predictability is best achieved through the application of the rule contained in the law applicable to the passive claim ('the insolvent debtor's claim'). Thus, 
if that law permits set-off, but the lex concursus denies it, the latter will be overridden. This is the approach that would be followed in the present day under English rules of private international law (that is, quite apart from the rule now imposed under Regulation 1346/2000 for cases to which it applies). In the current edition of Dicey, Morris and Collins, ${ }^{22}$ at paragraph 7-032 the learned editors, having drawn a distinction between procedural and substantive set-off (the former being concerned with the possibility that certain kinds of claim may be triable together according to the procedural rules of the lex fori), then state:

A set-off may, on the other hand, amount to an equity directly attaching to the claim and operate in partial or total extinction thereof; an example is the compensation de plein droit of French law. The question whether a set-off of this kind exists is one of substance for the lex causae, i.e. the law governing the claim which the defendant asserts has been discharged in whole or in part. (italics added; footnotes omitted)

In the passage quoted above, "the claim which the defendant asserts has been discharged in whole or in part" corresponds to the 'passive' claim, as between the creditor and the insolvent debtor, because that is the claim which would be enforced against the creditor (as defendant) by the insolvent debtor (as claimant). It can therefore be argued that the rule supplied by article 6 of the EC Regulation is in harmony with modern views of the appropriate way in which to resolve issues of set-off in international cases, and reflects the practice that would be followed in many jurisdictions (including England) even where the regulation itself is not applicable to the case in question. 


\section{$6 \quad$ But is this the 'correct' rule?}

For the purposes of the Global Principles Project however, it is appropriate to revisit the issue of set-off with an open mind as to the international acceptability of any rule whereby it is permissible to disapply the set-off law of the lex concursus in a way that enables a right of set-off to be claimable where it can be shown that legitimate expectations of the availability of such a right in the event of the counter-party's insolvency have accompanied a creditor's approach to its relationship with the debtor. That question, along with other issues concerning the appropriate limits to the role of the lex concursus, will become one of the focal points during the later stages of the Global Principles Project, and a vigorous debate can be anticipated. 


\section{Bibliography}

ALI Canadian Bankruptcy Law

American Law Institute Transnational Insolvency: Co-operation among the NAFTA Countries - International Statement of Canadian Bankruptcy Law" (Juris Publishing Inc Huntington 2003)

\section{ALI Mexican Bankruptcy Law}

American Law Institute Transnational Insolvency: Co-operation among the NAFTA Countries - International Statement of Mexican Bankruptcy Law" (Juris Publishing Inc Huntington 2003)

\section{ALI Principles of Cooperation}

American Law Institute Transnational Insolvency: Co-operation among the NAFTA Countries - Principles of Cooperation among the NAFTA

Countries" (Juris Publishing Inc Huntington 2003)

\section{ALI US Bankruptcy Law}

American Law Institute Transnational Insolvency: Co-operation among the NAFTA Countries - International Statement of United States Bankruptcy Law" (Juris Publishing Inc Huntington 2003)

Collins et al (eds) Conflict of Laws

Collins L et al (eds) Dicey, Morris and Collins on The Conflict of Laws $14^{\text {th }}$ rev ed (Sweet \& Maxwell London 2007)

Fletcher Challenge and Opportunity

Fletcher IF "Challenge and Opportunity: the ALI/III Global Principles Project" Paper presented at INSOL Annual Europe, Africa \& Middle East Conference (Cape Town South Africa 17-21 March 2007) 
Fletcher Insolvency in Private International Law

Fletcher IF Insolvency in Private International Law $2^{\text {nd }}$ ed (Oxford University Press Oxford 2005)

Omar Taxonomy

Omar PH Taxonomy of Guidelines and Principles in International Insolvency Unpublished

Westbrook 2002 Am Bankr LJ 1

Westbrook JL "Multinational Enterprises in General Default: Chapter 15, the ALI Principles, and the EU Insolvency Regulation" 2002 (76) American Bankruptcy Law Journal 1-42

Westbrook and Ziegel 1997 Brook J Int'l L 7-24

Westbrook JL and Ziegel JS "The American Law Institute NAFTA Insolvency Project" 1997 (23) Brooklyn Journal International Law 7-24

Westbrook Managing Defaulting Multinationals

Westbrook JL "Managing Defaulting Multinationals within NAFTA" in Fletcher IF, Mistelis L and Cremona M (eds) Foundations and Perspectives of International Trade Law (Sweet \& Maxwell London 2001)

\section{Register of court cases}

Re Eurofood IFSC Ltd [2006] ECR I-4137; [2006] BCC 397 (ECJ) 2 May 2006 Klempka and others (Administrators of ISA Daisytek SAS) v ISA Daisytek SA [2003] BCC 984 (Court of Appeal, Versailles) 4 September 2003 Re Daisytek-ISA Ltd [2003] BCC 562 (Ch D Leeds Registry) 16 May 2003

\section{Register of treaties and conventions}

EC Convention: Law Applicable to Contractual Obligations 19 June 1980 EC Regulation on Insolvency Proceedings 2002 
Istanbul Convention of the Council of Europe

\section{Register of Internet resources}

UNCITRAL Legis/ative Guide http://www.uncitral.org/ 19 Feb

UNCITRAL Legislative Guide [Found on internet]

http://www.uncitral.org/pdf/english/texts/insolven/05-80722 Ebook.pdf

[Date of use 19 February 2008]

UNCITRAL Model Law http://www.uncitral.org/ 31 Aug

UNCITRAL Model Law on Cross-Border Insolvency 1997 [Found on

internet]

http://www.uncitral.org/uncitral/en/uncitral texts/insolvency/1997Model.html

[Date of use 31 August 2007]

UNCITRAL Report of $39^{\text {th }}$ Session http://www.uncitral.org 11 Mar

UNCITRAL Report of $39^{\text {th }}$ Session UN Doc A/61/17 [Found on internet]

http://www.uncitral.org [Date of use $11 \mathrm{March}$ ]

\section{List of abbreviations}

$\begin{array}{ll}\text { ALI } & \text { American Law Institute } \\ \text { app } & \text { appendix } \\ \text { art } & \text { article(s) } \\ \text { ch } & \text { chapter(s) } \\ \text { COMI } & \text { centre of main interest(s) } \\ \text { ECJ } & \text { European Court of Justice } \\ \text { EEA } & \text { European Economic Area } \\ \text { esp } & \text { especially } \\ \text { III } & \text { International Insolvency Institute } \\ \text { InsReg } & \text { EU Insolvency Regulation } \\ \text { NAFTA } & \text { North American Free Trade Agreement } \\ \text { par } & \text { paragraph(s) }\end{array}$




$\begin{array}{ll}\text { pr } & \text { principle(s) } \\ \text { reg } & \text { regulation(s) } \\ \mathrm{s} & \text { section(s) } \\ \text { Triple-I } & \text { International Insolvency Institute }\end{array}$

